\title{
JOHN FRIEND MAHONEY M.D.
}

Our readers in many parts of the world will be saddened to hear of the death of John Mahoney. His name is known to all venereologists and will go down in medical history as that of the first man to demonstrate and test the treponemicidal power of penicillin at a time when a safe, effective, and rapid treatment for syphilis was a paramount need in the allied armed forces for replacing the hazardous and uncertain intensive arseno-therapy which was then in common use. In conversation, however, he characteristically refused to admit that he was deserving of any special praise for this work, giving much of the credit for his discovery to his "boys".

John Friend Mahoney was born at Fond du Lac, Wisconsin on August 1, 1889, and graduated M.D. at the University of Marquette in 1914. In the Great War, he served in Europe with the American Expeditionary Force, returning home in 1919 to join the United States Public Health Service. After various assignments, he was appointed Director of the Venereal Disease Reference Laboratory in 1929, and it was in this post that his high reputation in microbiology and serology was made. It was fortunate that during the second world war he held the additional post of Medical Director of the Seamen's Hospital at Staten Island, and, at the end of 1942, he was quick to appreciate penicillin as a safe and powerful anti-syphilitic remedy. This discovery and his further research on the subject brought him the Lasker award in 1946.
In 1948, he was appointed a member of the World Health Organization's Expert Committee on Venereal Diseases, being elected its chairman at its first meeting in Geneva. It is a tribute to his excellence in the art of chairmanship as well as to the genuine affection in which he was held by the members that he was re-elected at the next two meetings in Paris and Washington. Those who served with him on that committee will not forget his patience, kindness, and realism, and especially his good-humoured forbearance with those who at first could not completely share his faith in penicillin. The fact that his views ultimately prevailed and that treatment projects in many heavily infected areas were quickly put into effect must have resulted in the sparing of much misery and the saving of many lives.

In 1950, he was appointed Commissioner for Health for the City of New York, holding this high office until 1953 when he returned to his life's work as Director of the New York City Laboratories; this post he held until his death.

The secret of much of Mahoney's success can be found in his middle name, for he had that rare knack of making his colleagues feel that they had found a friend. To his wife and his two sons, his many friends will wish to send their sympathy and at least one Irish friend will add "God rest his soul".

$$
\text { G. L. M. McE. }
$$

\section{BOOK REVIEW}

An Atlas of the Commoner Skin Diseases. By Henry C. G. Semon and H. T. H. Wilson, 5th. ed., 1957. Pp. 384, 153 colour plates. (105s.).

In the preparation of the revised text of this well known atlas of skin diseases, Dr. Semon has had the assistance of Dr. H. T. H. Wilson of the Royal Northern Hospital, London. This edition not only maintains the important attributes of its predecessors but it is also considerably enlarged and more up to date in the text; in addition, sixteen new colour plates have been added.

I think most people would agree that Dermatology is the specialty par excellence in which there is need for a lifelike picture in the mind's eye to help the memory. Ordinary monochrome illustrations are a poor substitute for the living subject, but illustrations photographed from the living subject in natural colour provide the answer and a most satisfactory answer it is.

A minor failing of the earlier editions, in my judgment, was an occasional lack of balance between the different colour values, but both in this respect and in the brilliant rendering of minute detail these photographs are a fine, technical accomplishment.

The main achievement of the book is its unique value as a pictorial guide and, of necessity, the text is brief. Although it is not intended that the book should be comprehensive, it nevertheless contains much wisdom, the fruits of long experience, and it is admirably arranged in an easily accessible position with regard to each colour plate. Most valuable, too, are the many references throughout the volume to more specialized and fuller texts, and the atlas, used, as it was intended, in conjunction with these, will be of inestimable value both to the student and the practitioner. Needless to say, the book is beautifully produced, a tribute to the photographic skill of Dr. Arnold Moritz, and, although it is expensive, it is of excellent value and will make a cherished addition to any library.

A. J. G. 